\title{
Educational aid, symbolic power and policy reform: The World Bank in Ethiopia
}

\author{
Tebeje Molla* - Deakin University, Australia
}

\begin{abstract}
The World Bank uses a combination of financial and non-financial aid to influence educational reform in aid-recipient countries. Drawing on an interpretive policy analysis methodology and using Pierre Bourdieu's concept of symbolic power as a 'thinking tool', this article aims to shed light on the Bank's non-financial pathways of policy influence in the Ethiopian higher education policy space. Specifically, it identifies knowledge-based policy regulatory instruments of the Bank, including sector reviews, advisory activities, analytical reports and learning events. The key argument is that in order to understand the full extent of donor power in national education policy fields in sub-Saharan Africa, it is imperative to problematize less visible discursive means of policy imposition.
\end{abstract}

Keywords: Ethiopia, World Bank, development aid, higher education reform, symbolic power, Bourdieu

\section{Introduction}

In the globalizing world, no national education policy space is insulated from external influences. Policy agendas set in one corner of the world move fast to the other, with few or no barriers. This policy mobility has been made possible mainly through international, transnational and supranational organizations such as the World Bank, the United Nations Educational, Scientific and Cultural Organization (UNESCO), the Organisation for Economic Co-operation and Development (OECD), the World Trade Organization and the European Union (Dale, 2000; Moutsios, 2010; Mundy et al., 2016; Rizvi and Lingard, 2010). Despite differences in degree and scope, national education systems are influenced by one or more of these global policy actors.

This article specifically focuses on the influence of the World Bank in the Ethiopian higher education (HE) policy space. Ethiopia is a founding member of the World Bank. It was one of the three countries (the other two were Egypt and South Africa) that represented Africa at the Bretton Woods Monetary Conference (1-22 July 1944), which laid the foundation of what has come to be known as the Bretton Wood Institutions, namely the World Bank and the International Monetary Fund (IMF) - the two key international financial institutions. Ethiopia became a member of the World Bank (International Bank for Reconstruction and Development) on 27 December 1945 and received its first loan in 1950. It signed the International Development Association (IDA) Articles of Agreement on 11 April 1961 and received its first educational aid from this new arm of the Bank in 1966 (Kiros, 1990).

Ever since, the Bank has been one of the largest external sources of development aid in a wide range of sectors: road, power, agriculture, education and health. In 2017, Ethiopia received a total of over US $\$ 4$ billion in aid: about 25 per cent of this amount 
came from the World Bank, and the other 25 per cent from the US Government (see Figure 1 for trends of aid flow since the 1960s). As of November 2018, the World Bank has financed 27 education projects in Ethiopia, with a total cost of over US\$2.1 billion; and this is by far the largest World Bank education funding in a sub-Saharan African country. There are currently a number of active education projects funded by the Bank, including General Education Quality Improvement Project II, Education Results Based Financing Project and General Education Quality Improvement Program for Equity.

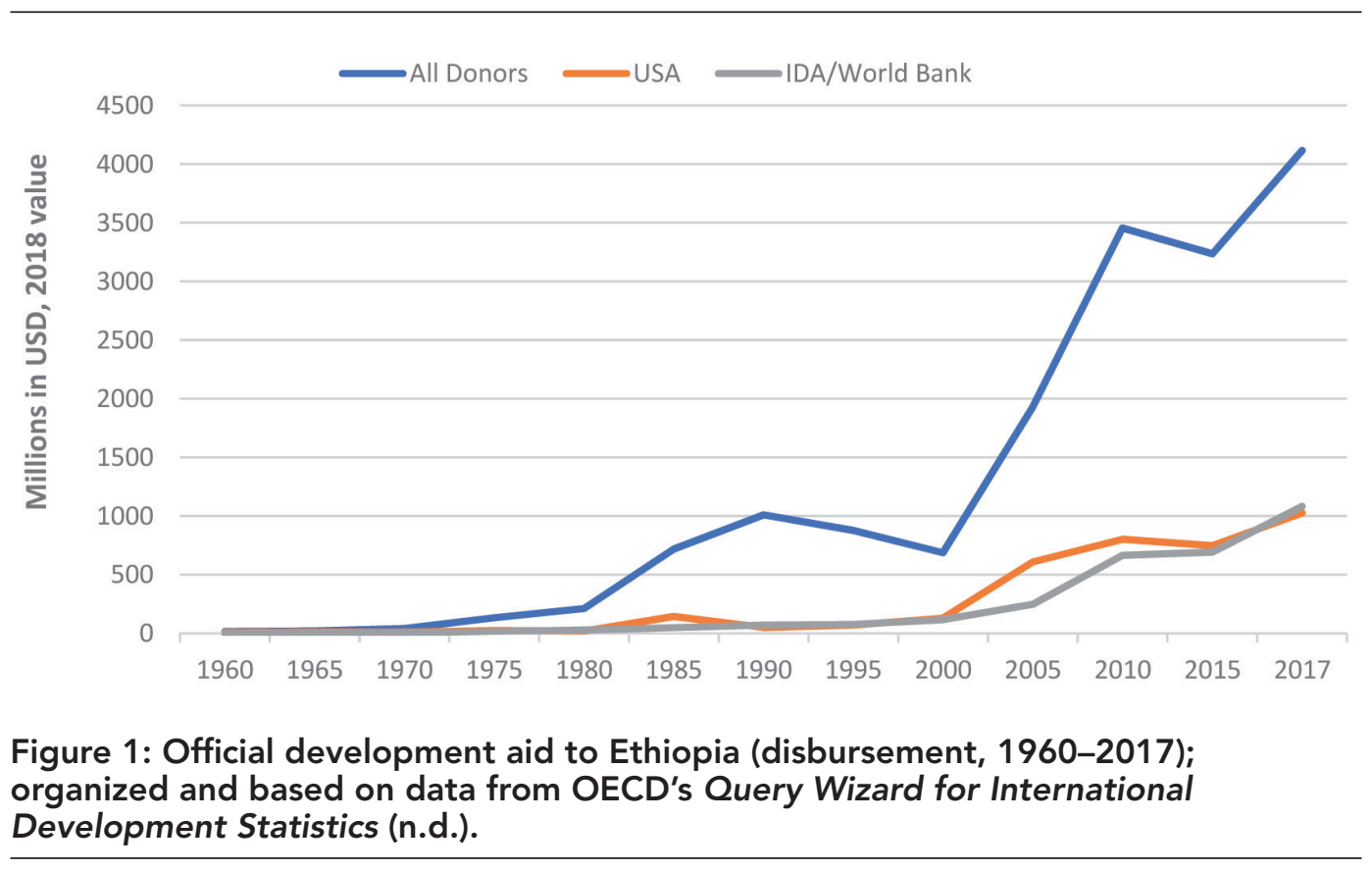

Since the end of the 1990s, the World Bank has repackaged its neoliberal policy agenda in what are referred to as Poverty Reduction Strategy Papers (PRSPs), and has increasingly drawn on knowledge-based pathways of policy influence (Molla, 2018, 2019) or what Shahjahan (2016: 694) calls 'epistemic tools of influence'. As a result, the Bank's instruments of policy imposition have become softer, subtler and (possibly) more effective. Despite such a shift in means of policy regulation, criticisms of World Bank activities typically focus on the conditions attached to the financial aid. The impact of the World Bank's non-financial educational development aid remains underresearched, if not neglected.

Taking the role of the World Bank in the Ethiopian HE reform as an empirical case, the article aims to address this knowledge gap. Its analytical focus is on specific instruments through which the Bank enacts its symbolic power to steer policy agendas in aid-recipient governments. The article specifically explains how the World Bank manages to infuse its potentially controversial neoliberal policy prescriptions into educational reforms in Ethiopia, and why national policy agents, despite strong alignment with external forces, claim ownership of the policy agenda. The findings of the analysis show that the World Bank uses various instruments of discursive dissemination (for example, research, consultancy, analytical reports and conferences) to induce compliance to its neoliberal policy prescriptions; and that these knowledgebased pathways of policy influence conceal the Bank's power to prescribe policy priorities and directions in Ethiopia's HE sector.

The remaining part of the article is organized in four main sections. The first discusses the analytical framework and methodological approaches of the study. The 
second presents a brief account of HE development in Ethiopia. The third identifies the World Bank's knowledge-based instruments of policy imposition. The fourth problematizes 'knowledge aid' of the World Bank, with a focus on shared denial of policy impositions by the Bank and government officials. The article closes with some concluding remarks.

\section{Analytical framework and methodology}

Drawing on Pierre Bourdieu's (1990) theory of practice, the national education policy space is seen as a field of action - a structured social space where agents interact and compete to maximize their positions. Internally, the policy space consists of interest groups and experts who mobilize evidence to formulate appropriate strategies to address the problem in question. Externally, as Mangez and Hilgers (2012: 194) have noted, national education policy fields are subjected to 'forces of an economic kind', including dominant groups within the state and global policy actors such as the World Bank. A Bourdieuian theory of practice suggests that actors effectively perform their roles in the field of action when they have relevant species of capital that define their positions and their strategic position-takings (Bourdieu, 2015). Global policy actors such as the World Bank have various forms of capital at their disposal: financial resources (economic capital), policy knowledge and expertise (cultural capital), relations and networks of influence (social capital) and legitimacy and recognition of other forms of resources (symbolic capital). In a policy process, the capability to impose one's own classifications, categories or discursive constructs cannot be possible without what Pierre Bourdieu calls symbolic power.

The World Bank is equipped with the necessary means of policy imposition, including symbolic power. The symbolic capital it has acquired in the form of legitimacy (as a special agency of the UN and subsequent, supposed impartial position), and recognition of its financial capacity and expertise (represented by its policy professionals and extensive field experience) have given the Bank a symbolic power, 'the power granted to those who have obtained sufficient recognition to be in a position to impose recognition' (Bourdieu, 1989: 23). Symbolic power is a power that is subtle enough to be unrecognized as domination/imposition but important enough to be recognized as legitimate and hence acceptable. Those subjected to it believe it is legitimate and even commonsensical. As well as providing much-needed loans to developing nations, international organizations such as the World Bank are seen as purposive agents with a substantial degree of power and autonomy, and have bureaucracies defined by stability, legality, technicality and rationality that enable them to exert discursive pressure (Barnett and Finnemore, 1999). In a policy field, symbolic power manifests when the dominant agent defines and justifies the pattern and object of the relationship in the field: that is, who should be included and why, and how agents in the field should interact and relate in the process. According to Bourdieu (1989: 23), the use of symbolic power rests on two conditions:

Firstly, as any form of performative discourse, symbolic power has to be based on the possession of symbolic capital... Secondly, symbolic efficacy depends on the degree to which the vision proposed is founded in reality ... Symbolic power is the power to make things with words. It is only if it is true, that is, adequate to things, that description makes things.

What is particularly interesting in this excerpt is that the viability of symbolic power partly depends on 'the degree to which the vision proposed is founded in reality'. 
In this respect, in the World Bank's educational development aid, the shift that gives priority to the use of evidence-based policy prescription implies a strategic measure to disguise policy prescription as 'knowledge services'. Unlike explicit and conventional conditionalities attached to financial aid, subtlety of knowledge-based regulatory instruments means that external and local actors are more likely to misrecognize policy impositions, resulting in what Bourdieu $(1991,1998)$ calls symbolic violence. This article outlines key instruments that the bank uses to translate its symbolic capital into symbolic power.

Critical policy analysis is drawn on as a methodological strategy. Viewed from a critical policy analysis perspective, policy actors contest and struggle to construct and circulate their messages through various instruments, including research and consultancy (Ball, 2005; Ozga, 2008; Taylor, 2004). Those with the necessary resources (such as funding, knowledge, recognition and legitimacy) can define certain issues as valid policy concerns while neglecting or discrediting alternative 'problems' and strategies. Therefore, a critical policy analyst should be conscious of both the power relations in policymaking, and the role of the social setting in mediating the meaning of the policy and its implementation and effects (Molla and Gale, 2018).

Qualitative data were drawn from a corpus of documents relevant to Ethiopian $\mathrm{HE}$ as well as project appraisal and implementation reports, sector reviews and policy briefs of the World Bank. Key texts reviewed include: Ethiopia - Education Sector Development Project (World Bank, 1998); Higher Education for Ethiopia: Pursuing the Vision (World Bank, 2003); Ethiopia - Post Secondary Education Project (World Bank, 2004); Higher Education System Overhaul (Committee of Inquiry, 2004); Ethiopia - General Education Quality Improvement Program for Equity Project (World Bank, 2017a); Higher Education Proclamation (first introduced in 2003) (FDRE, 2009); Council of Ministers Higher Education Cost-sharing Regulations (FDRE, 2003a); and Annual intake and enrolment growth and professional and program mix of Ethiopian public higher education: Strategy and conversion plan (MoE, 2008). In addition, selected regional policy reports and policy 'learning events' of the Bank are reviewed.

In the analysis, I traced policy influences of the World Bank using three indicators: (a) chronological sequence of the Bank's 'knowledge services' and key reform initiatives in the Ethiopian HE space, (b) the alignment of 'policy options' outlined in knowledge services of the Bank and actual HE reform elements embraced by the government, and (c) the availability of Bank funding to enact major reforms. To highlight instances of policy prescriptions, I put specific government reforms (for example, privatization, cost-sharing, programme mix of HE and performance-based funding initiatives) in juxtaposition with the 'policy options' embedded in what I call the knowledge aid of the World Bank. The findings are presented in two themes: knowledge-based instruments of policy imposition and shared 'misrecognition' of policy influence. These are discussed in turn. But first I will very briefly discuss the historical development of HE in Ethiopia.

\section{A brief account of higher education development in Ethiopia}

Compared with other African countries, where colonial powers laid the foundation of modern Higher Education institutions (HEls) much earlier, in Ethiopia HE development started far behind. For centuries, the main institution of higher learning has been the Ethiopian Orthodox Church education, also known as Abinet School. Westernstyle modern HE has a history of about seven decades. In this relatively short period, 
the system has passed through distinct transformations. Based on the combination of noticeable system-wide changes and national-level political transformations that affected the system, four stages of HE development in the country are identified. These are the genesis of modern HE (1950-60) during which the Imperial Government of Haile Selassie I established Addis Ababa University College (1950) as the first HEl, followed by other colleges and institutes; the consolidation of the 'national university' (1961-74) through the amalgamation of existing colleges under the Haile Selassie I University (established in 1961); incremental progress under a state of hardship, political turmoil and economic crisis (1975-late 1990s); and a period of extensive expansion and restructuring (2000-2010s).

The late 1990s was a landmark period in the transformation of HE systems in the developing world. With the prevalence of the knowledge economy discourse in the 'global education policy field' (Rizvi and Lingard, 2010), providers of educational development aid such as the World Bank reframed the value of HE in society as critical and committed to supporting reform efforts in developing countries such as Ethiopia (Molla and Cuthbert, 2018; World Bank, 1998). Locally, as part of its subscription to the structural adjustment programmes and the poverty reduction strategies of the IMF and the World Bank, the new Ethiopian Government introduced major macroeconomic reforms, during and after its unstable transitional period (Abegaz, 1999). Towards the end of the 1990s, the government turned its attention to the HE system and redefined its mission and organization in line with the nation's development goals and poverty reduction strategies. Accordingly, in 1999 the government commenced its HE expansion by announcing the establishment of four new regional universities, namely Bahir Dar, Debub, Jimma and Mekelle. By upgrading existing colleges, merging different institutions and establishing new institutions, in a span of about 15 years the government increased the number of public universities from two in 1998 to 31 in 2012, with ten more under construction.

The accelerated expansion notwithstanding, the Ethiopian HE system has faced enduring challenges in the areas of quality, relevance, academic freedom and equity. Partly owing to the current skewed investment towards HE, secondary education is poorly resourced and many students transition to the system without the appropriate level of preparation. The HE system is also dominated by underqualified young academic staff (Molla, 2018). The problem of the lack of relevance of the system is attributable to imported system models, political entanglement and the lack of a functional HEindustry partnership. Political intrusion and 'unfreedom' in Ethiopian universities also inhibit freedom of thought and open debate. Finally, despite considerable increases in participation, inequality in access to HE has also persisted along the lines of gender, socio-economic status, and political and geographical peripherality.

\section{Knowledge-based Instruments of policy imposition}

In the context of low-income countries, donors use a combination of financial and non-financial instruments to shape policy directions. The World Bank employs what Samoff (1992: 60) describes as an 'intellectual/financial complex of foreign aid' to publicize its 'policy options' in national education policy processes. Particularly, beginning in the mid-1990s, by redefining itself as a 'knowledge bank' that seeks to produce, disseminate and share knowledge as part of its development assistance for the developing world, the World Bank reintroduced a knowledge aid project as part of its broad development strategy (Klees, 2002, 2010). With a strong financial means at its disposal, the World Bank heavily invests in research and produces a large body 
of knowledge across a broad range of sectors and themes. In addition to its annual flagship reports such as the World Development Report, between 2004 and 2018, staff members of the Bank's Development Research Group have produced close to 2,000 journal articles (World Bank, 2019a). The Advisory Services and Analytics (ASA) of the Bank comprises sector reviews, 'knowledge-sharing workshops', policy notes and action plans. In 2017 alone, the World Bank delivered over 1,400 knowledge services and products in over 150 countries (World Bank, 2017b).

In a paper that analyses the language of the World Bank reports from 1946 to 2012, how the Bank operates is outlined:

Confronted with existing demands, its experts analyze numbers, but they also pay visits, realize surveys, and conduct missions to the field ... Afterwards, the bank proceeds to advise countries, suggest solutions, assist local governments and allocate its loans. (Moretti and Pestre, 2015: 2-3, emphasis in original)

The Bank follows the same pattern in its development work in Ethiopia (World Bank, 1998, 2003, 2004, 2017a). In the Ethiopian HE policy reform process, the World Bank has exercised its symbolic power in two ways: disguising policy prescriptions in consultancy and research, and setting frame references through analytical reports and 'learning events'. That is to say, the World Bank uses three broad categories of discursive policy regulatory instruments: sector review and consultancy; policy (thematic analytical) reports; and 'learning events'.

\section{Sector review and consultancy}

At the centre of the World Bank's knowledge support is what it refers to as technical assistance, which includes policy consultancy and sector review by its experts. During the formative years of HE reform in Ethiopia, the World Bank played key roles in setting policy directions and priorities. Policy experts from the Bank participated in the process of key policy developments such as the Higher Education Proclamation (No. 351/2003, revised as No. 650/2009), which sets a legal framework to guide institutional and system-wide changes (FDRE, 2009), and the Education Sector Development Programs (FDRE, 1998, 2002a, 2005, 2010, 2015) of the government, which outlined the reform directions of the HE system. The World Bank also carries out major sector reviews as part of its project appraisal process. Before it committed to funding the first Education Sector Development Program (1998-2002) and Post-Secondary Education Project (2004-8), the Bank delegated task forces led by its own policy experts to investigate reform and funding priorities in the education system (World Bank, 1998, 2003b). The task force that studied Ethiopian HE in the early 2000s published the result of the study, entitled Higher Education Development for Ethiopia (World Bank, 2003b), where it outlined specific policy options (for example, cost-sharing, funding formulas and strategic planning) that the Ethiopian Government should endorse. In 2004, with the aim of supporting the government in the implementation of the reforms, the World Bank (2010) approved a five-year post-secondary education project (US\$40 million).

The World Bank also commissioned expatriate consultants to devise a new HE financing system. First, it assigned Professor Bruce Chapman, the architect of the income-contingent HE charging system first implemented in Australia in 1989, as a leading consultant to investigate the possibilities and modalities of introducing tuition fees in public universities in Ethiopia. In his report, Chapman concludes, 'A charge is justified, and the best mechanism is collection depending on a graduate's income' 
(Chapman, 1999: 11). Accordingly, the Bank championed the introduction of user fees in $\mathrm{HE}$ in Ethiopia, and the issue came to be one of the policy priorities in the reform process in the early 2000s. And finally, in late 2003, following the promulgation of the Cost Sharing Regulations (No. 91/2003; FDRE, 2003a), the Ethiopian Government introduced a cost-sharing scheme in which students in public universities entered an agreement to share the cost of their study, to be paid back in the form of service or graduate tax from future earnings. It is a variation of the income-contingent loan system used in Australia, South Africa, the UK and other countries. In addition, on the request of the Ethiopian Government for technical guidance in restructuring the funding system, the World Bank delegated a Washington-based HE policy organization, the Institute for Higher Education Policy, to 'design a workable budgeting formula' for Ethiopia (Merisotis, 2003: 2). The consultancy report recommended a simplified block grant budgeting system that enables the government to use policy-driven funding priorities to steer public HEls towards meeting specific goals and requirements. The proposed financing system was also thought to be instrumental in improving the performance of the institutions and making them more efficient and competitive. The recommendation was endorsed by the Ethiopian Government and has now been implemented in the form of strategic plan agreements with public universities. Article 62 of the Higher Education Proclamation stipulates: 'Public institutions shall be funded by the federal government or states through block-grant system based on strategic plan agreements' (FDRE, 2009).

It is worth noting that to study education systems and policies in sub-Saharan Africa, the World Bank commissions expatriate experts who basically share its values and assumptions (Samoff, 2005; Teferra, 2004). Even when local experts are involved in such research projects, the terms of reference, benchmarks and indicators are set by the World Bank. These tend to reaffirm the official views and positions of the Bank, and have little effect in presenting alternative views of the problem in question.

\section{Table 1: World Bank's knowledge aid to Ethiopia's education system}

\begin{tabular}{|c|c|}
\hline $\begin{array}{l}\text { Categories of } \\
\text { knowledge products }\end{array}$ & Examples of knowledge products \\
\hline Policy briefs & $\begin{array}{l}\text { - Early childbirth and under-five malnutrition in Ethiopia (2017) } \\
\text { - Survey of ICT and education in Africa: Ethiopia country report } \\
\text { (2007) }\end{array}$ \\
\hline $\begin{array}{l}\text { Education system } \\
\text { assessment }\end{array}$ & - SABER student assessment: Ethiopia country report (2009) \\
\hline $\begin{array}{l}\text { Impact evaluation and } \\
\text { policy research }\end{array}$ & $\begin{array}{l}\text { - Ethiopia: Enhancing human development outcomes through } \\
\text { decentralized service delivery (2007) } \\
\text { - Ethiopia: Urban labour market: Challenges and prospects (2007) }\end{array}$ \\
\hline $\begin{array}{l}\text { Sector reviews and } \\
\text { publications }\end{array}$ & $\begin{array}{l}\text { - Textbook provision for all in Ethiopia: Lessons learned from the } \\
\text { General Education Quality Improvement Project (2017) } \\
\text { - Improving the performance of Ethiopian universities in science } \\
\text { and technology: A policy note (2017) } \\
\text { - Education in Ethiopia: Strengthening the foundations for } \\
\text { sustainable progress (2005) } \\
\text { - Higher education development in Ethiopia: Pursuing the vision } \\
\text { (2004) }\end{array}$ \\
\hline
\end{tabular}

Source: (World Bank, 2019b) 


\section{Policy reports}

The World Bank produces models and ideas, and advances debates on key policy issues through publishing thematic and analytical reports. Policy reports and analytical work of the Bank draw on the results from a series of commissioned studies, reports on lessons of experience, collections of best practices and comparative evaluation of performances of different countries in the field of HE policy and practice. Usually the reports present new directions in the Bank's strategy and associated 'policy options' to be used as a reference for national policy actors. For the World Bank, the aim of the 'analytical studies' is to build the knowledge base that allows intelligent design of policies to build human capital and reduce poverty. For instance, beginning in the late 1990s, the World Bank has published widely consulted education policy reports: Knowledge for Development (1999), Can Africa Claim the 21st Century? (2000), Higher Education in Developing Countries: Peril and Promise (2000), Constructing Knowledge Societies: New Challenges for Tertiary Education (2002), Accelerating Catch-up: Tertiary Education for Growth in Sub-Saharan Africa (2009) and World Bank Education Strategy 2020 (2011). Most often the policy reports and related analytical works include statistical data and 'best practices' on student enrolment, system diversification, financial schemes and governance models from different countries. In order to increase their impact, the Bank circulates key publications free of charge via its website and other channels.

These analytical and policy reports have been produced and disseminated with the aim of influencing HE reforms or - in the words of Bank staff - serving 'as catalysts for initiating discussions and, ultimately, reforms' (Salmi et al., 2009: 109) in aid-recipient countries. That assumption appears to be true, at least in the case of Ethiopia where the World Bank's influence is evident both in the content and language of key HE policy documents developed in the past 15 years (to 2019). For example, the government's '70/30 program mix' policy (MoE, 2008) strongly echoes the Bank's knowledge economy discursive constructs. The policy mandates that public university in-takes are on the basis of placement of 70 per cent into the Science, Engineering and Technology streams and 30 per cent into the Social Sciences and Humanities streams. Likewise, the emphasis on human capital formation, differentiation and efficiency in the new education development roadmap (MoE, 2019) resonates discursive constructs of the Bank.

\section{'Learning events'}

The World Bank globalizes its HE policy discursive constructs through policy-learning platforms such as thematic conferences, workshops and seminars at international, regional and national levels. Education policy experts organize workshops to publicize major policy ideas. Some of the major 'learning events' on education in sub-Saharan Africa include: Improving Tertiary Education in Sub-Saharan Africa: Things that work (23-5 September 2003, Accra, Ghana); International Conference on Quality Assurance in Higher Education in Africa (15-17 September 2008, Dakar, Senegal); The Partnership for Higher Education in Africa (PHEA) University Leadership Forum (23-5 November 2008, Accra, Ghana); Conference of Ministers of Education in Africa (COMEDAF IV) (24-5 September 2009, Addis Ababa, Ethiopia); National Conference on World-Class Universities (27 September 2010, Abuja, Nigeria); Workshop on Sustainable Financing and Governance of Regional Initiatives in Higher Education in Africa (21 March 2011, Ouagadougou, Burkina Faso); High-Level Forum: Higher Education for Science, Technology and Innovation: Accelerating Africa's Aspirations (13 March 2014, Kigali, 
Rwanda); The African Higher Education Summit (10-12 March 2015, Dakar, Senegal); First Africa-China-World Bank Education Partnership Forum: Higher Education, Science and Technology (10-15 July 2017, Beijing/Shanghai, China); The 14 $4^{\text {th }}$ World Bank Group TICAD Seminar 'Education Sector in Africa: Schooling for Learning' (3 September 2018, Tokyo, Japan); and the Fifth PASET Forum: Destination Digital Africa: Preparing our Youth for the Future (20-2 May 2019, Kigali, Rwanda).

In Ethiopia, the World Bank team participated in in-country workshops and seminars purportedly to facilitate broad consensus on policy priorities and reform directions. Technical assistance missions engaged in a series of 'dialogues' with the Ethiopian Government and set the terms of reference for changes in the education system (FDRE, 2002a; World Bank, 1998, 2004). As part of the process of developing the Education Sector Development Plan (1998) and the national Capacity Building Strategy (FDRE, 2002b), the World Bank organized a series of consultancy workshops and seminars. The Bank also supported the participation of government officials in thematic regional conferences organized in other African countries. For instance, the Bank, together with the government of Rwanda, organized a forum on Higher Education for Science, Technology and Innovation, where representatives of the governments of the five countries participating (Rwanda, Ethiopia, Mozambique, Senegal and Uganda) discussed the issue of research capacity-building and the role of the PhD (Kigali Communiqué, 2014: 2). These learning events aim at bringing various stakeholders together to debate on policy agendas and alternatives, and thereby to build broad consensus on carefully articulated key policy options and priorities. More often than not the terms of reference of thematic conferences and commissioned sector reviews are set by the Bank, and there is little or no space to accommodate emerging, divergent views and perspectives. The ASA simply serves the Bank to marshal evidence to enhance the credibility of its policy argument.

Notwithstanding the Bank's effort to use research and consultancy as vectors of its agenda, conditions of aid to HE are no secret. For the Bank to approve funding for projects and programs in HE in developing countries, two key criteria should be met: the need to reform and willingness to reform (World Bank, 2002). That is to say, the involvement of the Bank depends on the gravity of the problem that necessitates reform and the political commitment of governments to accept and implement reform prescriptions (or policy options, as the Bank prefers to call them). In practice, the need to reform is a result of an intentional construction of a policy problem by the Bank. In its financial and non-financial involvements, the Bank is proactive, not reactive - it contacts aid-recipient governments with packages of programme loans and policy initiatives (Torres, 2009). The World Bank commissions sector reviews and produces analytical works to show problems of a particular sector, and outline strategies to address them. Most often, it also indicates its interest to approve project or programme funding if necessary. Against this backdrop, poor governments in Africa have little or no reason not to show willingness to reform. In other words, the World Bank uses its knowledge power to initiate interest for reform and uses its strong financial resources to implement the required reform in those countries. It creates crisis that needs to be averted and nominates itself - usually by virtue of its experience, knowledge and financial power - as a viable agent to deal with it. This supports what Naomi Klein (2007) highlights in The Shock Doctrine: in order for neoliberal agents to induce their ideas and ideals into national policy spaces, there should be a reasonable 'shock' coupled with obedience of the aid-seeker as a necessary. Neoliberal agents such as the World Bank take advantage of extraordinary conditions (for example, deep economic crises, authoritarian regimes and natural disasters) to insert their agenda into aid-recipient governments. 


\section{Policy imposition and symbolic violence}

Well before the consolidation of the global education policy field (Rizvi and Lingard, 2010), donors had very limited involvement in Ethiopia's education policy field. At a time when most newly liberated African states were largely dependent on former colonial governments, Ethiopians were able to conceive, plan and execute their own policies and development programmes. For example, Ethiopia's first and largest system-wide educational review (1971/72) was fully commissioned and monitored by the Ministry of Education and Fine Arts. The review was conducted by 14 task forces and five small working groups with 81 participants, of whom 51 were Ethiopians drawn from the national university, the Ministry of Education and other government agencies (Habte, 1999; MoEFA, 1972). Although many foreign experts from the World Bank, UNESCO, the International Labour Organization and the Harvard University Development Advisory Service played a consultancy role during the review process, Ethiopians chaired all but one task force (Habte, 1975). For the most part, the foreign experts were residents in Ethiopia and would have considerable understanding of the socioeconomic context they were investigating. There was an understanding that donors could not be trusted to address urgent policy issues in the nation. Dr Aklilu Habte (1975: 16), the former president of Ethiopia's national university and one of the local experts who served in the international advisory committee during the review process, expressed a scepticism about donors' involvement in national policy processes: 'A group of people come; they plan a beautiful thing for you; they don't involve you; and when they go, nobody knows about it and it is shelved. It stays on the shelf as a beautiful thing.' Against the backdrop of such local awareness, although the World Bank aimed to use the review outcome as 'a basis for identification of projects', it did not try to impose its prescriptions from outside. Instead, the Bank 'lent its moral and financial backing to a self-assessment by the Ethiopians themselves' (Harbison, 1973: 50). Not only had Ethiopia a strong pool of well-educated and active local experts but the policy space was open for such actors.

Today it is a different story. Donors have significant leverage in the national policy space. As noted above, the World Bank has committed over US $\$ 2$ billion (including funds channelled through social rehabilitation, basic services protection and rural capacitybuilding programmes as well as poverty reduction strategy credits) to the Ethiopian education sector. As a result, the influence of the Bank in the institutionalization of privatization, the cost-sharing scheme and the block grant budgeting system in Ethiopian HE is well documented (Molla, 2013, 2014a, 2014b, 2018). However, there is a strong tendency among senior government officials and World Bank representatives to deny any sort of policy imposition. A senior government official in the Ministry of Education (MoE) of Ethiopia tended to limit the Bank's role to financial aid: 'The World Bank's involvement aims at giving impetus to the transformation process. It is more of a budgetary support. The government could use the support in any way it wants' (Moso, interview, 18 August 2010). Similarly, when asked to comment on the role of the World Bank in restructuring the HE system, another senior government official in the MoE preferred to emphasize his government's ownership of the reforms: 'HE reforms in Ethiopia do have Ethiopian premise. We have our own causes ... Our reforms are Ethiopian both in form and mission' (Moha, interview, 23 October 2010). Likewise, from the Bank's side, knowledge-driven policy regulatory instruments are framed as means of facilitating 'policy changes' (Salmi and Bassett, 2010) or 'the crossfertilisation of relevant regional experiences' (World Bank, 2002: xxvii). The World Bank (2002, 2007) misleadingly characterizes its knowledge aid as 'knowledge sharing' or 
'learning activities'. For its staff, the Bank is a 'knowledge-sharing institution' whose non-lending support to HE systems in developing countries is simply an act of helping 'governments consider options about possible higher education reforms' (Salmi et al., 2009: 106, emphasis added).

In reality, when policy ideas are entrenched in loan agreements (as attachments with a much-needed fund), they become less option and more imposition. Furthermore, as the policy idea mainly flows from the World Bank to national actors, it cannot be considered knowledge sharing - it should rather more appropriately be labelled knowledge aid. In other words, the process of knowledge production and dissemination is simply a way of 'manufacturing consent' on the Bank's policy priorities and agenda. Policy reports and analytical works serve to facilitate policy initiatives and changes, and as such they are, in the words of a senior official in the Bank, 'primarily vehicles for selling projects' (quoted in Goldman, 2005: 135). The Bank uses knowledge-based policy regulatory instruments mainly to legitimatize its predefined policy choices. As a result, not surprisingly, findings and recommendations of commissioned sector reviews and policy studies at different levels and localities conform to the Bank's discourse of market rationality and human capital formation. In the case of Ethiopia, the World Bank has effectively used these knowledge-based regulatory instruments to publicize its key reform agenda, including cost-sharing, privatization, system diversification and formula funding. As noted already, the Bank commissioned experts who could help the government restructure governance and funding arrangements of the HE sector. In light of the recommendations of the experts (for example, Committee of Inquiry, 2004; Chapman, 1999; Merisotis, 2003; World Bank, 2003), the government introduced a HE law (FDRE, 2003b, 2009) and a cost-sharing scheme (FDRE, 2003a).

Even so, neither the Bank nor the government like to acknowledge the influence of imposed ideas in the Ethiopian HE policy space. This denial of policy imposition can in part be explained by the implicitness of the regulatory instruments of the Bank, which have created a relationship in which local policy actors take the disguised impositions for granted. This internalized domination/subordination is what Bourdieu (1991, 1998) refers to as symbolic violence, which occurs when both the dominated and the dominant take for granted the disguised imposition of meaning and power as a legitimate condition. Bourdieu uses the act of gift to show how symbolic violence operates. For him, gift giving is a 'mechanism through which power is exercised and simultaneously disguised' (Bourdieu, 1991: 23). Notwithstanding implicitly, the giver and the recipient know that the gift should be acknowledged appropriately. To put it differently, the acknowledgement of debt generates 'a durable feeling toward the author of the generous act' (Bourdieu, 1998: 102, emphasis in original).

Symbolic power operates quietly. As Han (2017: 9) observes, because of its subtle form, neoliberal instrument of governance 'escapes all visibility', and 'wherever power does not come into view at all, it exists without question'. Given its immense symbolic power, the World Bank is equipped with the necessary means of creating doxic compliance to policy imposition. The act of gift (including grants and concessional (low-rate) loans in the case of a donor-recipient relationship) expresses and legitimizes hierarchy. With this condition as a backdrop, the Bank uses its knowledge-based policy regulatory instruments to impose discursive constructs, disguise power relations and establish domination. By providing a substantial grant associated with the policy process, the Bank appears to reveal hierarchies where it holds some form of superiority over the recipient governments. In so doing, it secures the necessary recognition: 'in one move, the gift transaction could reinforce relations of power and dependence, yet 
be intuitively perceived by both participants and observers through the common - and highly legitimate - lens of "charity"' (Eagleton-Pierce, 2011: 18).

The interaction of the World Bank and the Ethiopian Government in the higher education policy space meets two conditions of symbolic violence: subtlety of instruments of power and complicity of social agents. The subtlety of its policy regulatory instruments has enabled the Bank to enact its power as persuasion rather than sanction. Bourdieu stresses, 'Any symbolic domination presupposes on the part of those who are subjected to it a form of complicity which is neither a passive submission to an external constraint nor a free adherence to values' (quoted in Bourdieu and Wacquant, 1992: 168). In the aid field, symbolic power provides the dominant agent with the capability to enforce its own classification and meaning. The knowledge-based pathways of policy influence have also given the Ethiopian Government grounds to claim strong ownership of policy ideas and to downplay the role of external actors in the policy process. When local actors recognize external policy influence, they externalize it to unspecific sources or to 'general principles of scientific rationality' (Schriewer, 2000: 331). As a result, the policy prescriptions go unchallenged through the national process disguised as local 'inventions' that fit local needs. Symbolic violence is 'symbolic in the sense that it is achieved indirectly and without overt and explicit acts of force or coercion' and it is 'an act of violence precisely because it leads to the constraint and subordination' of social actors (Connolly and Healy, 2004: 15, emphasis in original). For example, in the case of Ethiopia, national policy agents have accepted key discursive constructs such as human capital formation, knowledge economy, economic efficiency and strategic expansion as a universalized web of ideas rather than ideologically loaded structures of a particular global agent; that is, the World Bank. This denial of policy imposition has consequently complicated research efforts to trace sources and effects of such agendas.

In closing, whereas the discussion in this section mainly focuses on educational development aid of the World Bank, it should be noted that the Bank has not been the only external agent that has been actively involved in the Ethiopian HE policy space. For example, HE management and policy experts from Voluntary Service Overseas from the UK have played key roles as advisors, policy researchers and acting directors of the newly established system oversight institutions, namely the Higher Education Strategy Centre and the Higher Education Relevance and Quality Assurance Agency. Moreover, among others, the Government of the Netherlands has funded HE projects aimed at improving the institutional capacities of public universities (Molla, 2013, 2018). Other bilateral agencies such as the United States Agency for International Development, the German Technical Cooperation, the Norwegian Council for Higher Education Programme for Development Research and Education, and the Swedish International Development Agency are among the key external supporters of the system (Semela and Ayalew, 2008). Nevertheless, unlike the World Bank, other donors have not consistently aligned their support to the HE system with the broad poverty reduction programme and the sectoral (macroeconomic) restructuring at large, and hence their involvement in HE has had little or no direct connection with the neoliberal policy discourses that framed the reform process. Here, educational aid of the World Bank refers to concessional lending (credits) and grants as well as non-financial supports of the IDA branch of the Bank. 


\section{Conclusion}

This article is intended to specifically highlight the World Bank's knowledge-based pathways of education policy influence in Ethiopia. Notwithstanding the local rhetoric of ownership of reform agendas and processes, the Bank has played critical roles in policy reform and institutional restructuring of the HE sector. In addition to funding projects and programmes, the Bank increasingly draws on knowledge aid as a pathway of policy influence. For the Bank, knowledge aid is a form of governance exercised through discursive practices that include setting priorities for policy reform, establishing terms of reference and defining examples of 'best practice'. Through its sector reviews, consultancy services, analytical reports and 'learning events', the World Bank elevates its key policy constructs to a position of utmost significance, such that aid-recipient governments rarely question the relevance of the prescriptions to their respective contexts.

The subtlety of the knowledge-based policy regulatory instruments has significant practical effects. To begin with, knowledge aid conceals power. It has enabled the World Bank to exercise a veiled dominance in the policy process and avoid local resistance to its neoliberal policy prescriptions. Likewise, the subtlety of policy prescription tools means that the national policy agents can downplay donor influence and claim ownership of agendas. Relatedly, the Bank's insistence on evidence-based policy tends to 'obscure contested meanings' and 'functions to impose a conceptual and methodological orthodoxy that may undermine education reform and marginalize innovation' (Samoff, 2012: 143). The policy discourse imposes meanings and assumptions of the World Bank and rarely accommodates local realities and aspirations. In the interaction of external forces and local policy agents, the degree of autonomy of a policy field 'is measured precisely by its ability to refract external demands into its own logic' (Johnson, 1993: 14). In the case of Ethiopia, it is difficult to say that the government has meaningfully refracted policy prescriptions of the World Bank. Even so, this article does not make a claim that all reform elements in Ethiopian HE are impositions from donors such as the World Bank. It is most likely that the Ethiopian Government has had its own policy preferences and priorities. What is equally evident is that concessional loans, grants and 'knowledge services' of the Bank have in particular been crucial for educational development in Ethiopia; that non-financial educational aid of the Bank is a subtle but powerful means of policy imposition; and that both external and local agents tend to misrecognize these impositions. It is imperative for the government to be mindful of imported policy ideas and make sure they are responsive to contextual factors, including societal needs and aspirations.

\section{Notes on the contributor}

Tebeje Molla is an Australian Research Council (ARC) Discovery Early Career Researcher Award (DECRA) Fellow in the School of Education, Deakin University, Australia. His research focuses on transnational educational policy processes, educational inequality and policy responses, graduate research training policy and teacher professional learning. Theoretically, his work is informed by critical sociology and a capability approach to social justice and human development. 


\section{References}

Abegaz, B. (1999) Aid and Reform in Ethiopia. Washington, DC: World Bank.

Ball, S.J. (2005) Education Policy and Social Class: The selected works of Stephen J. Ball. London: Routledge.

Barnett, M.N. and Finnemore, M. (1999) 'The politics, power, and pathologies of international organizations'. International Organization, 53 (4), 699-732.

Bourdieu, P. (1989) 'Social space and symbolic power'. Sociological Theory, 7 (1), 14-25.

Bourdieu, P. (1990) The Logic of Practice. Trans. Nice, R. Stanford: Stanford University Press.

Bourdieu, P. (1991) Language and Symbolic Power. Ed. Thompson, J.B. Trans. Raymond, G. and Adamson, M. Cambridge: Polity Press.

Bourdieu, P. (1998) Practical Reason: On the theory of action. Stanford: Stanford University Press.

Bourdieu, P. (2015) 'Men and machines'. In Knorr-Cetina, K. and Cicourel, A.V. (eds) Advances in Social Theory and Methodology: Toward an integration of micro- and macro-sociologies. London: Routledge, 304-17.

Bourdieu, P. and Wacquant, L.J.D. (1992) An Invitation to Reflexive Sociology. Chicago: University of Chicago Press.

Chapman, B. (1999) Reform of Ethiopian Higher Education Financing: Conceptual and policy issues (Economics of Education 2). Washington, DC: World Bank.

Committee of Inquiry (2004) Higher Education System Overhaul: Report of the Committee of Inquiry into Governance, Leadership and Management in Ethiopia's Higher Education System. Addis Ababa: Ministry of Education.

Connolly, P. and Healy, J. (2004) 'Symbolic violence, locality and social class: The educational and career aspirations of 10-11-year-old boys in Belfast'. Pedagogy, Culture and Society, 12 (1), 15-34.

Dale, R. (2000) 'Globalization and education: Demonstrating "common world educational culture" or locating a "globally structured educational agenda"?'. Educational Theory, 50 (4), 427-48.

Eagleton-Pierce, M. (2011) 'Symbolic power in the WTO'. Paper presented at the British International Studies Association (BISA) Annual Conference, Manchester, 27-29 April 2011.

FDRE (Federal Democratic Republic of Ethiopia) (1998) Education Sector Development Program, 1998/09-2001/02. Addis Ababa: Federal Democratic Republic of Ethiopia.

FDRE (Federal Democratic Republic of Ethiopia) (2002a) Education Sector Development Program II (ESDP-II) 2002/03-2004/05: Program action plan (PAP). Addis Ababa: Ministry of Education.

FDRE (Federal Democratic Republic of Ethiopia) (2002b) Yemsfetsem Akim Ginbata (Capacity Building) Strategy and Programs. Addis Ababa: Ministry of Information.

FDRE (Federal Democratic Republic of Ethiopia) (2003a) 'Council of Ministers Regulation No. 91/2003: Higher Education Cost-Sharing Council of Ministers Regulation'. Federal Negarit Gazeta, 9 (85), 2335-9.

FDRE (Federal Democratic Republic of Ethiopia) (2003b) 'Proclamation No. 351/2003: Higher Education Proclamation'. Federal Negarit Gazeta, 9 (72), 2235-63.

FDRE (Federal Democratic Republic of Ethiopia) (2005) Education Sector Development Program III (ESDP-III) 2005/06-2010/11 (1998 EFY-2002 EFY): Program action plan (PAP). Addis Ababa: Ministry of Education.

FDRE (Federal Democratic Republic of Ethiopia) (2009) 'Proclamation No. 650/2009: Higher Education Proclamation'. Federal Negarit Gazeta, 15 (64), 4976-5044.

FDRE (Federal Democratic Republic of Ethiopia) (2010) Education Sector Development Program IV (ESDP-IV) 2010/11-2014/15 (2003 EC-2007 EC): Program action plan (PAP). Addis Ababa: Ministry of Education.

FDRE (Federal Democratic Republic of Ethiopia) (2015) Education Sector Development Program V (ESDP-V) 2015/16-2019/20 (2008 EC-2012 EC): Program action plan (PAP). Addis Ababa: Ministry of Education.

Goldman, M. (2005) Imperial Nature: The World Bank and struggles for social justice in the age of globalization. New Haven: Yale University Press.

Habte, A. (1975) 'Changing relationships in international co-operation'. Prospects, 5 (1), 12-18.

Habte, A. (1999) 'The future of international aid to education: A personal reflection'. In King, K. and Buchert, L. (eds) Changing International Aid to Education: Global patterns and national context. Paris: UNESCO Publishing, 46-59.

Han, B.-C. (2017) Psychopolitics: Neoliberalism and new technologies of power. Trans. Butler, E. London: Verso.

Harbison, F.H. (1973) The Development of Nation-Wide Learning Systems: A sector approach for assessment of national development from a human resources perspective (Research Program in Economic Development Discussion Paper 37). Princeton: Princeton University. 
Hopper, R., Salmi, J. and Bassett, R.M. (2008) 'Transforming higher education in developing countries: The role of the World Bank'. In Global University Network for Innovation Higher Education in the World 3: Higher education: New challenges and emerging roles for human and social development. Basingstoke: Palgrave Macmillan, xl-xliv.

Johnson, R. (1993) 'Editor's introduction: Pierre Bourdieu on art, literature and culture'. In Bourdieu, P. The Field of Cultural Production: Essays on art and literature. Ed. Johnson, R. New York: Columbia University Press, 1-28.

Kigali Communiqué (2014) 'Higher Education for Science, Technology and Innovation: Accelerating Africa's aspirations'. Communiqué, Kigali, Rwanda, 13 March 2014. Online. https://tinyurl.com/y6dussrl (accessed 17 August 2019).

Kiros, F.R. (1990) Implementing Educational Policies in Ethiopia (World Bank Discussion Papers Africa Technical Department Series 84). Washington, DC: World Bank.

Klees, S. (2002) 'World Bank education policy: New rhetoric, old ideology'. International Journal of Educational Development, 22 (5), 451-74.

Klees, S.J. (2010) 'Aid, development, and education'. Current Issues in Comparative Education, $13(1), 7-28$.

Klein, N. (2007) The Shock Doctrine: The rise of disaster capitalism. New York: Metropolitan Books.

Mangez, E. and Hilgers, M. (2012) 'The field of knowledge and the policy field in education: PISA and the production of knowledge for policy'. European Educational Research Journal, 11 (2), 189-205.

Merisotis, J.P. (2003) Higher Education Funding in Ethiopia: An assessment and guidance for next steps. Washington, DC: World Bank. Online. https://tinyurl.com/y2mswr55 (accessed 17 August 2019).

MoE (Ministry of Education) (2008) Annual Intake and Enrolment Growth and Professional and Program Mix of Ethiopian Public Higher Education: Strategy and conversion plan. Addis Ababa: Ministry of Education.

MoE (Ministry of Education) (2019) Ethiopian education development roadmap. Addis Ababa: Ministry of Education.

MoEFA (Ministry of Education and Fine Arts) (1972) Education: Challenge to the nation: Report of the Education Sector Review. Addis Ababa: Ministry of Education and Fine Arts.

Molla, T. (2013) 'The Neoliberal Policy Agenda of the World Bank and Higher Education Reform in Ethiopia: The problem of inequality in focus'. Unpublished PhD thesis, Monash University, Melbourne.

Molla, T. (2014a) 'Knowledge aid as instrument of regulation: World Bank's non-lending higher education support for Ethiopia'. Comparative Education, 50 (2), 229-48.

Molla, T. (2014b) 'Neo-liberal policy agendas and the problem of inequality in higher education: The Ethiopian case'. Policy Futures in Education, 12 (2), 297-309.

Molla, T. (2018) Higher Education in Ethiopia: Structural inequalities and policy responses. Singapore: Springer.

Molla, T. (2019) 'Human development optimism and political pitfalls in Ethiopia'. Forum for Development Studies, 46 (2), 367-91.

Molla, T. and Cuthbert, D. (2018) 'Re-imagining Africa as a knowledge economy: Premises and promises of recent higher education development initiatives'. Journal of Asian and African Studies, 53 (2), 250-67.

Molla, T. and Gale, T. (2018) 'Positional matters: School leaders engaging with national equity agendas'. Journal of Education Policy, 1-19. Online. https://tinyurl.com/y27v8dyr (accessed 14 August 2019).

Moretti, F. and Pestre, D. (2015) Bankspeak: The language of World Bank Reports, 1946-2012 (Pamphlet 9). Stanford: Stanford Literary Lab.

Moutsios, S. (2010) 'Power, politics and transnational policy-making in education'. Globalisation, Societies and Education, 8 (1), 121-41.

Mundy, K., Green, A., Lingard, B. and Verger, A. (2016) 'Introduction: The globalization of education policy - key approaches and debates'. In Mundy, K., Green, A., Lingard, B. and Verger, A. (eds) The Handbook of Global Education Policy. Chichester: Wiley Blackwell, 1-20.

OECD (Organisation for Economic Co-operation and Development) (n.d.) 'OWIDS: Query Wizard for International Development Statistics'. Online. https://stats.oecd.org/qwids/ (accessed 23 November 2018).

Ozga, J. (2008) 'Governing knowledge: Research steering and research quality'. European Educational Research Journal, 7 (3), 261-72.

Rizvi, F. and Lingard, B. (2010) Globalizing Education Policy. London: Routledge. 
Salmi, J. and Bassett, R.M. (2010) 'Transforming higher education in developing countries: The role of the World Bank'. In Peterson, P., Baker, E. and McGaw, B. (eds) International Encyclopedia of Education. 3rd ed. Oxford: Elsevier, 590-6.

Salmi, J., Hopper, R. and Bassett, R.M. (2009) 'Transforming higher education in developing countries: The role of the World Bank'. In Bassett, R.M. and Maldonado, A. (eds) International Organizations and Higher Education Policy: Thinking globally, acting locally? New York: Routledge, 99-112.

Samoff, J. (1992) 'The intellectual/financial complex of foreign aid'. Review of African Political Economy, 53, 60-75.

Samoff, J. (2005) 'The pursuit of effective external support and persisting external influence - direct, indirect, and negotiated'. Paper presented at the Nuffic Conference, "A Changing Landscape: Making support to higher education and research in developing countries more effective", The Hague, 23-25 May 2005.

Samoff, J. (2012) '"Research shows that...": Creating the knowledge environment for Learning for All'. In Klees, S.J., Samoff, J. and Stromquist, N.P. (eds) The World Bank and Education: Critiques and alternatives. Rotterdam: Sense Publishers, 143-57.

Schriewer, J. (2000) 'World system and interrelationship networks: The internationalization of education and the role of comparative inquiry'. In Popkewitz, T.S. (ed.) Educational Knowledge: Changing relationships between the state, civil society, and the educational community. Albany: State University of New York Press, 305-43.

Semela, T. and Ayalew, E. (2008) 'Ethiopia'. In Teferra, D. and Knight, J. (eds) Higher Education in Africa: The international dimension. Chestnut Hill, MA: Center for International Higher Education, 159-207.

Shahjahan, R.A. (2016) 'International organizations (IOs), epistemic tools of influence, and the colonial geopolitics of knowledge production in higher education policy'. Journal of Education Policy, 31 (6), 694-710.

Taylor, S. (2004) 'Researching educational policy and change in "new times": using critical discourse analysis'. Journal of Education Policy, 19 (4), 433-51.

Teferra, D. (2004) 'The World Bank prescription for Ethiopian higher education: The missing antidote in "pursuing the vision"'. Online. http://www2.bc.edu/\%7Eteferra/World_Bank_Study_Eth_High_Edu.html (accessed 26 April 2008).

Torres, C.A. (2009) Education and Neoliberal Globalization. New York: Routledge.

World Bank (1998) Program Appraisal Document on a Proposed International Development Association Credit in the Amount of US\$100 Million Equivalent to the Federal Democratic Republic of Ethiopia for the Education Sector Development Program (Report No. 17739-ET). Washington, DC: World Bank. Online. https://tinyurl.com/y4acokro (accessed 17 August 2019).

World Bank (2002) Constructing Knowledge Societies: New challenges for tertiary education. Washington, DC: World Bank.

World Bank (2003) Higher Education Development for Ethiopia: Pursuing the vision. Washington, DC: World Bank.

World Bank (2004) Project Appraisal Document on a Proposed Credit in the Amount of SDR 27.3 Million (USD 40 Million Equivalent) to the Federal Democratic Republic of Ethiopia for a Post Secondary Education Project (Report No. 28169-ET). Washington, DC: World Bank. Online. https://tinyurl.com/yxbswd5x (accessed 17 August 2019).

World Bank (2007) Building Knowledge Economies: Advanced strategies for development. Washington, DC: World Bank.

World Bank (2010) Post-Secondary Education Project: Implementation completion and results report. Washington, DC: World Bank.

World Bank (2011) World Bank Education Strategy 2020 - Learning for All: Investing in people's knowledge and skills to promote development. Washington, DC: World Bank.

World Bank (2017a) Program Appraisal Document on a Proposed IDA Grant and Multi-Donor Trust Fund Grant in the Amount of SDR 213,600,000 (US\$300 Million Equivalent IDA Grant) and US\$140 Million Equivalent MDTF Grant to the Federal Democratic Republic of Ethiopia for the General Education Quality Improvement Program for Equity (GEQIP-E) (Report No. 121294-ET). Washington, DC: World Bank. Online. https://tinyurl.com/yy2u9jsw (accessed 17 August 2019).

World Bank (2017b) World Bank Annual Report 2017. Washington, DC: World Bank.

World Bank (2019a) 'Journal articles by the staff of the World Bank's Development Research Group (2004-present)'. Online. https://tinyurl.com/y5rx9h4r (accessed 17 August 2019).

World Bank (2019b) 'Smarter education systems to achieve learning for all'. Online. https://smartereducation.worldbank.org/projects (accessed 2 September 2019). 